\title{
Belydenis: Objektiewe waarheid of eksistensiële uitdrukking van geloof?
}

\author{
L J S Steenkamp \\ Sentrum vir Teologiese Navorsing en Toerusting (Afd A) \\ Universiteit van Pretoria
}

\begin{abstract}
Confession: Objective truth or existential expression of belief?

Confession of belief originates when someone (the believer or the church) is so touched existentially by the Person, Jesus Christ, that he or she cannot help declaring that Jesus is the living Lord. This confession, therefore, becomes a lifestyle which has to be relived again and again. For this reason we never testify to our own insights or rational ideas about God, but to this meeting with God in Jesus Christ. Thus, it becomes clear that confession is different to religious lyrics or the knowledge of abstract truths which are only communicated rationally; it imlies a decision which carries a risk, but at the same time it simply has to be repeated again and again in an existential way by the believer.
\end{abstract}

\section{WAT IS BELYDENIS?}

Wanneer daar oor die belydenis nagedink word, is die eerste saak wat na vore kom die vraag: wat is belydenis? 'n Rekenkundige stelling ( $\operatorname{soos} 2 \times 2=4$ ) of 'n historiese bewering (soos Jan van Riebeeck het in 1652 aan die Kaap geland) kan nie bely word nie. Die betrokke stellings laat mens in jou hart koud; dit word aanvaar en bevestig as feitelik deur gebruikmaking van relevante wetenskaplike bewysvoering. Belydenis ontstaan daar waar iets, waar iemand, my só persoonlik, só eksistensieel in die hart raak dat ek dit met my hele lewe wil en moet beaam. Daarom word die martelare van die vroeë kerk confessores, belyers, genoem. Belydenis is daarom nie iets intellektueel of verstandelik alleen nie, dit is ook prakties-eksistensieel in die sin dat die belyer se totale mens daarin gegryp en in besit geneem word. Dit word daarom vir die belyer 'n lewenswaarheid en lewenswyse wat telkens wér gesê en geleef moet word. Wanneer Jesus Christus in die ruimte van die Christelike kerk bely word as die weg, die waarheid en die lewe, is dit 'n waarheid wat Christene se harte verower, hulle verlossing bely en hulle in diens stel. Die Nederlandse Geloofsbelydenis (Artikel 27) bely: 
Ons glo en bely ...'n heilige vergadering van almal wat waarlik in Christus glo, wat almal hulle volle saligheid in Jesus Christus verwag en in sy bloed gewas is, getreilig en verseël deur die die Heilige Gees .... Verder is hierdie heilige kerk nie geleë in, gebonde aan of beperk tot 'n sekere plek of sekere persone nie, maar is dit oor die hele wêreld versprei en verstrooi ...

(Nederduitsch Hervormde Kerk van Afrika 1993:152)

Hierdie belydenis onderstreep dat die kerk nie anders kan as om belydende kerk te wees nie. So 'n belydende kerk kan dan ook nie die vraag ontsnap oor die eksistensiële betrokkenheid van lidmate wanneer daar by elke erediens bely word soos en saam met die kerk van alle tye nie. Die kerk word dus telkens gekonfronteer met die wesenlike vraag of hierdie waarheid geléf word soos in die geval van die confessores van die vroeë Christelike kerk? Werk dit dus werklik hartsveranderend in die lewens van lidmate? Druk dit iets uit van die 'nogtans' wat so sentraal staan in die BybelsReformatoriese regverdigingsleer, waarmee volgens Luther die kerk staan of val (articulus stantis et cadentis ecclesiae), naamlik dat dit wat die gelowige kerk bely, ingaan teen alles wat evident, begrypbaar is (Heidelbergse Kategismus, Sondag 23, Antwoord 60). Christene bely dus met die risiko dat hulle belaglik gemaak kan word. Ons bely nie in die eertse plek om ons erns, ons moed en ons ortodoksie voor mense te laat klink nie; ons bely omdat ons in die teenwoordigheid van God te staan gekom het en daarom nie anders kan as om hierdie ontmoetingsgebeure te verwoord en te leef nie. Dit beteken uiteraard om die Woordgebeure te laat kommunikeer en nie self aan die woord te kom nie. Belydenis is daarom iets anders as religieuse liriek. Ons bely nie onsself of ons eie insigte nie, maar die ontmoeting met die 'Gans Andere'. Daarom is belydenis altyd anders as religieuse liriek; dit impliseer ' $n$ beslissing wat ' $n$ risiko inhou maar terselfdertyd nie anders kan as om gesê te word nie. Daarom word nuwe belydenisse ook altyd gebore in tye van krisis en diepe beproewing in die lewe van gelowiges en die kerk. Belydenis is daarom ook nooit die voorreg, of self die reg van slegs pedikante en teoloë nie. Elke mens wat voor God in Jesus Christus te staan kom, word tot beslissing geroep. Belydenis maak daarom die belyer waarlik vry, vry veral van die self (Van Niftrik 1953:25). 


\section{BELYDENIS AS ESISTENSIEËLE GEBEURE}

\subsection{Belydenis as kommunikatiewe gebeure}

Wanneer daar besin word oor die belydenis van gelowiges gaan dit uiteraard oor spreke, antwoord en ontmoeting wat tussen God en belyer plaasvind. Die eerste vraag sou dan kan wees: hoe praat God? Die brief aan die Hebreërs (1:1) gee 'n aanduiding van die pluraliteit van God se Woord aan mense: 'In die verlede het God baie keer en op baie maniere met ons voorvaders gepraat deur die profete'. Die onderskeid sou getref kon word waar God Hom direk tot mense soos Abraham, Moses en Elia rig en dan ook waar daar sprake van middelike spreke is, soos daar waar God deur byvoorbeeld drome, visioene en sy dade in die geskiedenis met mense praat. Waar God deur dade praat, is daar natuurlik sprake van mense soos die profete wat die daadwoorde ontleed en interpreteer, sodat die Woord van God met mense kan kommunikeer binne die gegewe konteks. Wanneer die spreker van die Woord stil is, is die Woord ook stil.

God praat egter op finale wyse deur Jesus Christus. Hy is die eintlike spreker van die Woord - dié Persoon wat die gelowige en die kerk in die Bybel ontmoet. Maar ook sy Woord ontmoet die gelowige en die kerk deur die getuienisse van mense. Dit is egter duidelik dat hierdie getuies en draers van die Woord nie op 'n koue kliniese wyse verslag doen van blote feite soos 'n historikus of 'n joernalis nie. Gelei deur die Gees word die Woord as ontmoetingsgebeure proklamerend en interpreterend getuig. Dit wil natuurlik nie sê dat God se Woord maar net blote mensewoord is nie, dit wil egter beklemtoon dat God se Woord in mensetaal na ons toe kom en die waarheid, Jesus Christus, in die ontmoeting telkens Woord word.

Die wonder waar die Woord van God in mensewoorde verneem word, gebeur waar hierdie woorde vir my iets begin sê, wanneer dit my in my menslike eksistensie só oorweldigend aanspreek en só in beslag neem, dat dit inderdaad finale en genoegsaam antwoorde gee op my lewensvrae en lewensnood. As daar gevra word na 'n omskrywing van die begrip die belydenis, antwoord Pont (1985:524) dat 'n belydenis nooit selfstandig ontstaan nie. Belydenis is altyd antwoord, die antwoord van 'n mens, 'n kerk op die selfopenbaring van God in Jesus Christus. Dit wil sê: antwoord op die eksistensiële ontmoeting met die Woord van God naamlik, Jesus (is) die Here (Fil 2:11; 1 Kor 12:13). Dit is duidelik dat 'n belydenis meer is as 'n gewone verstandelike uitspraak of formulering van 'n standpunt of uitkoms, want dit spel 'n eksistensiële lewenswaarheid uit, 'n waarheid wat geglo word. Hierdie belydenis-as-antwoord lei dan ook tot die ontstaan van die gemeente van gelowiges. 


\subsection{Belydenis en Woord van God}

Die fondament van die kerk is die Woord van God, die Heilige Skrif as getuienis van die lewende fondament van die kerk, Jesus Christus. Sonder hierdie fondament kan daar nie kerk wees nie. Die Skrif as geopenbaarde Woord van God het Goddelike gesag - dit sê ons op grond van die getuienis van die Heilige Gees. Hierdie gesag word bevestig deur die vervulling van voorspellings wat in die Skrif voorkom. Verder is Christus die sleutel tot die verstaan van die Ou en Nuwe Testament. Dit is die Skrifbeskouing wat uit die belydenisskrifte van die die Reformatoriese kerke gegroei het (Breytenbach 1982:47).

Waar ons die term belydenis in die sin van die leer of doctrina gebruik, wat veral gedurende die Reformasie ontstaan het, staan Christus ook in die belydenis sentraal. Die Nederduitsch Hervormde Kerk stel in Artikel I van die huidige Kerwet en Bepalings dat die kerk gegrond is op die Bybel as Woord van God en dat die belydenis in die drie formuliere van eenheid uitgedruk word. In Artikel XI.4 word dit herbevestig naamlik, 'Die Kerk weer uit sy midde alles wat die belydenis weerspreek'. Breytenbach (1982:48) meen dat dié uitspraak verwys na Artikel I en gevolglik beteken dat alles wat die geloof in die Drie-enige God weerspreek uit die kerk geweer moet word en nie soseer hulle wat die formulering van die belydenis weerspreek nie.

Wanneer die vraag na God se spreke deur die belydenis ter sprake kom, moet die vraag na die wese en funksie van die belydenis aan die orde gestel word. Belydenis is uiting van geloof, soos dit blyk op bepaalde plekke in die Nuwe Tetament (Fil 2:6-11; Kol 1:15-20; 1 Tim 3:16). Die kerk kom tot belydenis daar waar gelowiges met krisis in 'n bepaalde lewensituasie gekonfronteer word. Die kerk bely te midde van so ' krisis met aan die een kant die kerugma en aan die ander kant die lewenswerklikheid. Die kerk, soos die mense in die Bybel, is geroep om te praat, om die Woord wat die kerk aanspreek, te proklameer. In die lied en gebed en daar waar die evangelie geleer en gepreek word, ontstaan belydenis. Alhoewel die belydenis grenslyne vir die prediking trek, kan die prediking van tyd tot tyd oor daardie grenslyne stoot. Die belydenis put uit die Skrif maar daarmee is die Skrif tog nie uitgeput nie. Daarom kan daar nooit sprake wees van belydenisdwang nie want dit sou die Woord verarm en verslaaf. Die belydenis is om die rede prinsipieel veranderbaar en kan hoogstens tydelike betekenis hê.

Alhoewel die menslikheid van die belydenis beklemtoon moet word kan die belydenis by geleentheid tog wel Woord van God word. Dit gebeur daar waar die belydenis die Woord van God dra, waar dit my eksistensieel aanspreek en my lewensvrae finaal antwoord. Dit gebeur daar waar die belydenis ontmoeting word met die Heer wat bely word. Alhoewel die primêre gesag van die Skrif vanselfsprekend die 
belydenis altyd toetsbaar aan die Skrif maak, is dit egter die dilemma van geloofsdenke dat die een wat getoets moet word, in 'n sekere sin bepaal hoe die Skrif gelees word omdat dit funksioneer as die bril van die kerk. Hoe onbedoeld ook al, word aan die belydenis só 'n sakrosankte karakter verleen (Velthuysen 1985b:366-369). Juis hier lê die gevaar van verstarring van belydenis en geloof, hier waar die spreekreël in der waarheid die reël van die geloof word. Die groot vraag is hoe hierdie bedreiging wat inderdaad ook 'n verleiding vir kerk en gelowige is, oorkom kan word? Dit lyk net moontlik om uit hierdie probleem te kom waarin die Rooms-Katolieke Kerk so volledig vasgeval het, as die kerk en gelowiges saam met die belydenis telkens opnuut buig voor die God van die Woord, in ontmoeting met Jesus die Here.

Die kerk het deur die eeue die lewende eksistensiële uitdrukking van geloof verwoord deur dit in belydenisuitsprake vas te vang en oor te dra aan komende geslagte, wat op hulle beurt die hart en wese van die belydenis alleen kon ontdek in ' $n$ eie unicke en persoonlike ontmoeting met die Heer van die kerk. Die persoonlike handeling van belydenis en die vaslegging daarvan in formules wat gelowiges onderling deel, kan van mekaar onderskei word maar kan eintlik nie van mekaar geskei word nie, want dit kan lei tot of subjektivering of objektivering van die waarheid wat bely word. Die geloof van die individuele gelowige kan gevolglik nie op sigself staan nie, maar is altyd in 'n verhouding met die geloof van die geloofsgemeenskap waarbinne en vanwaaruit hulle leef en getuig. Hierdie dialektiek van die persoonlike eksistensiële ontmoeting met God, wat sodra dit in woorde bely is, telkens weer dwing tot 'n formulering daarvan, word telkens weer gegrond in die persoon van Jesus wat die kerk as Here getuig aan die wêreld.

\subsection{Belydenisskrif, belydenis en dogmavorming}

Daar moet onderskei word tussen belydenisskrifte, belydenis en dogma. Belydenisskrifte is die skriftelike neerslae van belydenisse waarin die esistensiële geloof van die kerk verwoord is. Pont (1985:524) maak die stelling dat die posisie van die belydenisskrif ten opsigte van die Heilige Skrif sekondêr is. Hierdie begrip is volgens hom egter ' $n$ betreklike begrip aangesien die belydenisskrif niks anders as die Heilige Skrif, die regula fidei, wil sê nie. Dit funksioneer as die kort in mensewoorde saamgevatte essensie van die regula fidei. Die rede waarom die belydenisskrif as sekondêr beskryf word, is omdat dit as mensewoorde, tydelik en daarom altyd hersienbaar is aan die hand van die Heilige Skrif. Histories gesproke, kom ons belydenisskrifte (confessio) in die krisistye van die Kerkhervorming tot stand. Die verstaan van die Heilige Skrif word in dié geskrifte verwoord. Die geloofsdenke van die Reformatoriese Kerk word dus daarin vervat. Die belydenisskrif gee so die aard en karakter; die 'persoonlikheid' 
van die kerk, weer. Dit is die middel waardeur die kerk afgegrens word van nie-kerk en valse kerk. Dit is ook die instrument waarmee die selfverstaan van die kerk teenoor die wêreld en ander kerke verantwoord word. Dit is uiteindelik ook aanduiding van die wyse waarop die kerk op die fondamente van die Woord gebou is. Dit vorm ook die ingange waarlangs die Woord in die kerk inspraak het (Velthuysen 1985a:373).

'n Probleem wat die kerk met groot erns sal moet oorweeg is dat baie lidmate dit toenemend moeiliker vind om die drie belydenisskrifte eksistensieel te bely. Die gevaar is uiteraard altyd daar dat die nasê van dit wat deur ander in ander tye en omstandighede geformuleer is, kan eindig in koue, onpersoonlike onbetrokkenheid en selfs in letterknegtery. Daar is weinig lidmate wat die drie belydenisskrifte se inhoude as selfverstaan van die belydende kerk hulle eie gemaak het. Dit sweef inderdaad meestal slegs soos skadus oor lidmate en veral kinders se koppe wanneer dit Sondae tydens die erediens voorgelees word. Die probleem kan aan meer as een oorsaak toegeskryf word. Die wyse van voordrag kan belangrik wees aangesien dit baie te make het met die eksistensiële ontmoeting wat so deur gelowiges beleef moet word. Die belydenis moet dalk meer gebid en gesing word as wat dit verstar in die blote voorhou van koue formules.

Die probleem word verder verswaar omdat daar in die debat oor die belydenis soveel uiterste opvattings oor die belydenis uitgespreek word. By sommige lidmate is daar die vrees vir belydenisdwang. Sommiges, word beweer, bring die belydenisskrifte ernstig in gedrang omdat hulle oortuig is dat dit tot formuleringsdwang lei. Ander wil dit onveranderd handhaaf omdat hulle beweer dat die belydensskrifte die waarheid suiwer en vir alle tye geformuleer het. Vir sommiges is die belydenis, soos uitgedruk in die belydenisskrifte, ' $n$ vesting waarin hulle veilig voel en van waaruit hulle hulle vyande bestook. Vir ander weer is dit ' $n$ museum vol interessante, ouderwetse rariteite. Baie lidmate wat nie so gepolariseerd teenoor mekaar betreffende die belydenisskrifte staan nie, handhaaf ' $n$ beleefde onverskilligheid teenoor die belydenisskrifte omdat dit by geleentheid interessant en selfs aktueel in die prediking geïnterpreteer word. Deist (1994:63) maak die stelling wanneer hy oor die teologie van die Nederduitsch Hervormde Kerk praat dat:

In konfessionalisme vorm (denominasionele) konfessies 'n juridiese afdwingbare kanon vir die verstaansproses, terwyl dit hier gaan om die (algemene én besondere) kerklike belydenisse as oriëntasiepunte vir ' $n$ proses waarin ook die belydenisskrifte self as kontekstuele produkte van die geloofsgeskiedenis van die kerk funksioneer en wat daarom kritieskreatief geresepteer moet word .... Daarom was die Hervormde Kerk 
korrek toe hulle in die beginjare van hulle teologiese fakulteit teologie wou bedryf ... en (aan) die belydenisskrifte as verstaanstradisie eerder as 'n verstaanskanon beskou het.

Gemser (1944-45:49) handhaaf 'n gesonde balans in die verband wat sekerlik as tydige waarskuwing kan dien in die huidige debat oor die rol en funksie van die belydenisskrifte:

[O]ns wil die Skrif liewer onbevange nader, nóg gevangene in 'n dwangbuis van die tog ook menslike leersisteme van 'n sogenaamde 'gelowige' wetenskap, nóg in die oop hemp van 'n sogenaamde vrye, onbevooroordeelde, onderstellingslose wetenskap. Ons staan skepties teenoor altwee.

Wat die saak baie moeilik maak is dat die toegang tot die geloof hoofsaaklik verkry word deur hierdie geartikuleerde geloof soos dit in belydenisskrifte verwoord is . Daar bestaan dus nie eintlik iets soos 'n direkte toegang tot die Skrif nie. Dit is daarom onmoontlik om die Skrif te lees sonder die bril van die gefikseerde belydenis as leer van die kerk. Voordat ons immers die Bybel optel om dit te lees, glo ons dat ons in dié geskrifte te make het met die Woord van God. Die gevolg van hierdie hermeneutiese sirkel waarin die teologie beweeg, is dat die belydenis as gefikseerde belydenis de iure gewysig kan word, maar de facto 'n posisie verkry het wat die wysiging daarvan feitlik onmoontlik maak (Breytenbach 1982:50; Velthuysen 1982:58). Vasgevang in hierdie sirkeldenke kan stagnasie maklik die einde van die belydenis as eksistensiële ontmoeting met die Persoon van Jesus die Here, deur wie ons die Drie-enige God bely, beteken (Berkhof 1973:32). Dit kan tot gevolg hê dat die kerk die bekende formules net telkens uit die stof haal, blink vryf en tot 'n volgende keer te bêre. Die vraag is of dit nie juis die probleem van die post-Kopernikaanse gemeenskap geword het nie - 'n wêreld waarin die lewende God moes plek maak vir objektiewe formules en hoogstens 'n idee van God - 'n wêreld en kerk wat so hard geskud is deur Nietzsche met sy uitspraak dat God dood is, dood in die kerk omdat die belydenis gestol het in dooie formules aangaande God.

Mens kan dus nie sê dat waar belydenisskrifte aanwesig is, ook noodwendig geloof en egte eksistensiële belydenis teenwoordig is nie. Daar kan egter wel gesê word dat waar daar geloof en dus belydenis aanwesig is, loop dit vroeër of later uit op ' $n$ belydenisskrif. Die rede hiervoor is dat belydenis ook meer as 'n private aangeleentheid is. Geloof en belydenis soek altyd gemeenskap. In opregte belydenis 
sit daar iets van sendingdrang. In 'n belydenis is daar ook van polemiek en afwysing sprake. 'n Belydenisskrif word gevolglik nooit net op 'n goeie dag 'gemaak' as die kerk daarna voel nie. 'n Belydenisskrif word gebore uit die nood van die oomblik. Wanneer die kerk getuig van die regte geloof maak die kerk 'n beroep op die Woord. Die Bybel is immers die norm waarop die kerk gerig word in leer en lewe. So word daar in die belydenis inderdaad ' $n$ teken opgerig van die geloof van die kerk (Van Niftrik 1961:26; vgl ook Küng 1991).

Die sistematiese ordening van Bybelse materiaal lei tot 'n kerklike leer. Hierdie leer van die kerk manifesteer sigself in leerstukke of dogmas. In die teologie van die Rooms-Katolieke Kerk word die dogmas as openbaringswaarhede gewaardeer. Dit kom dus daarop neer dat die Roomse Kerk in die onfeilbare leergesag van die kerk cor die bindende uitleg van die Bybel beskik. Die Bybel is dus in die Rooms-Katolieke Kerk nie meer vry teenoor die kerk nie - dié kerk het die Bybel gevange geneem. So word die waarheid die besit van die kerk wat daartoe aanleiding gee dat die ampte 'n magsgroep word wat kan manipuleer met die waarheid waaroor hulle beskik. Vir die protestantse kerke geld dogmas egter slegs as formulerings; menslike formulerings wat die waarheid, Jesus Christus, net in soverre kan begryp en weergee as wat die belyer na daardie waarheid op pad is. Volgens Protestantse kerke het die kerk nooit die waarheid nie; die kerk glo en bely die waarheid. Formulering van dogmas sou dus herhaal kon word, maar dan alleen voor en in ontmoeting met die waarheid self. 'n Verdere probleem is die vraag wat kom eerste: belydenis of dogma? Gee die belydenis aanleiding tot nuwe dogmavorming of roep dogmavorming nuwe belydenis op? In die beantwoording van dié vraag lyk dit of ons hier te doen het met 'n sirkelverbintenis wat baie moeilik, indien wel, gebreek kan word. Belydenis gee inderdaad aanleiding tot dogmavormig, terwyl nuwe dogmas altyd neig om deel van die belydenis te word.

\subsection{Belydenis as eksistensiële lewenswerklikheid}

Eerste-eeuse Jode, soos veral blyk uit die uitsprake van Jesus, het hulle skuldig gemaak aan die verabsolutering van die letter van die Wet en so tragies die gees en bedoeling van die Wet en die ware gehoorsaamheid aan die Woord van God verloor. Dit is ongetwyfeld waar dat Christene dieselfde fout kan begaan deur die ware betekenis van die Christelike geloof te verloor wanneer die belydenis van die kerk as 'n suiwer rasionele saak voorgehou word. Botha (1982:31) stel dit so: 'Die belydenisse was nooit bedoel om rasioneel en kunstig voorbereide dokumente te wees nie, maar wel geskrifte om die lewende geloof van die kerk tot uitdrukking te bring ....' 
Pannenberg (1987:142-145) wys daarop dat geloof wat bely en geleef word, rondom 'n Persoon wentel, dié van die Verlosser, Jesus Christus. Die belydenis 'Jesus is die Here' word algemeen aanvaar as die eerste belydenis van die geloof van die vroeë kerk. Feit is egter dat die oomblik toe hierdie belydenis in woorde uitgedruk is, het dit verdere vrae opgeroep soos: hoe moet gelowiges Jesus as Verlosser as mens en as God verstaan, hoe moet die verhouding van die Seun enersyds met die Vader en andersyds met die Heilige Gees verstaan word? Vrae soos dié wat in die vroeë kerk gevra is en vandag steeds herhaal word, is nie gevra uit nuuskierigheid of om spekulatiewe redes nie - dit kom telkens op uit die egte geloofsworsteling van gelowiges vir wie die belydenis van Jesus as die Here, 'n eksistensiële saak is en nie bestaan uit die slaafse nasê van oorgelewerde formules nie. Volgens Ott (1981:397) is die wese van die kerk 'n gebeure. Hierdie gebeure-karakter van die kerk maak dat die kerk altyd weer word terwyl dit tog ook reeds daar is. Dit is op die wyse dat die kerk as belydende kerk werklik kerk kan wees daar waar gelowiges eksistensieel God ontmoet. Bonhoeffer (1972a: 39-42) beskou die kerk as Christus eksisterende gemeente. Dit is vir hom die wyse waarop Christus in die wêreld teenwoordig is, waar Hy tegelyk Heer van die gemeente en broeder in die gemeente word. In verband met hierdie teenwoordig wees van Christus as persoon in die gemeente vra Koekemoer (1995:598) die kritiese vraag, naamlik op welke persoonlike struktuur Hy teenwoordig is. Bonhoeffer se antwoord op die vraag is dat Christus se ontologiese struktuur pro me is. Koekemoer (1995:598) wys daarop dat hierdie pro me die volgende implikasies het:

Jesus Christus pro me is die voorloper, die eersgeborene van al die gelowiges wat Hom volg; en Jesus is pro me in die sin dat Hy in my plek (plaasbekledend), in die plek van die gelowige staan. So is Hy dan ook die nuwe mensheid. Hy staan waar die ganse mensdom moes staan .... Hierdie een God-mens, Jesus Christus, is nou teenwoordig in die kerk in sy pro me struktuur; as Woord, as Sakrament en as gemeenskap. So leef die kerk in die wêreld.

Dit is verstaanbaar dat die passie en innerlike worsteling wat in hierdie eksistensiële gebeure deel word van elke belyer se lewe en van die kerk se teologiebeoefening, aanleiding gee tot rusteloosheid en selfs stryd. Trouens wanneer die intensheid in die gesprek van die kerk oor die belydenis ontbreek, is dit inderdaad ' $n$ baie gevaarlike teken wat die gevolg kan wees van 'n dooie geloof in woorde en wette waarin die lewende persoon van 'Jesus die Here' en die eksistensiële verhouding met hierdie 
lewende Here nie meer bestaan nie, waar die kerk dan nie meer die Heer aanbid nie maar slegs die belydenis oor die Heer. Die kerk wat so bely, loop ongetwyfeld die gevaar dat die Here wat so deur dooie koue onpersoonlike formules 'bely' word, kan vervaag in ' $n$ onpersoonlike begrip of idee - dat dieselfde fout so gemaak word wat filosowe maak wat meen om deur middel van rasionele beredenering God te vind en te bewys, 'n god wat slegs 'n begrip bly, 'n produk van die mens se verstand. Selfs erger is die situasie wat sedert die begin van die modernisme 'n skaduwee oor die teologie gewerp het van 'n god wat slegs 'n projeksie van die mens is. Van God kan dan gepraat word as 'n Deus emiritus - 'n geëmeriteerde God. In hierdie koue rasioneel oorheersde denkklimaat het die kerk en gelowiges die persoonlik-eksistensiële verhouding met God verloor deur in die plek daarvan God as 'n veraf koue idee in teologiese sisteme in te bou. Die mensbeskouing van die post-Kopernikaanse tyd waarin die menslike vryheid feitlik 'n sakrale karakter verwerf het, het aanleiding gegee tot 'n idealistiese beskouing van die mens wat die mens as skepper en onderhouer van die ideale samelewing gesien het.

Alhoewel die mens fenomenale vooruitgang op elke lewensterrein ervaar het, het die besef uiteindelik met die deurbreking van postmoderne denke deurgebreek dat mense vir die eerste maal in hulle geskiedenis oral, op elke lewensterrein net voor hulleself te staan gekom het - voor hulleself en die wêreld wat deur al die uitvindings van die verstand verbrou is. Die implikasie van hierdie besef, dat die mens Hercules van die wêreld wou wees en die wêreld op sy of haar skouers neem, het tot 'n skokkende besef gelei. Die mens wat vervreemd geraak het van natuur, medemens en God het weer begin soek na relasies. Waar mense hulle vryheid en waardigheid tot hoogste (en enigste) doel verhef, word daardie mens vir sy of haar medemens 'n wolf. Daarom sal die kerk moet besef dat die krisis wat die gesekulariseerde samelewing ervaar, alleen te bowe gekom kan word waar die mens, allereers die individuele mens, maar ook in gemeenskap, God in Jesus die Here ontmoet. 'n Waarlik eksistensiële ontmoeting lei spontaan in verwondering voor God tot 'n lewende belydenis wat getuienis word voor die wêreld. In hierdie ontmoeting vind die bevrydende besef plaas dat ek, die belyer self skuldig is, dat die belydenis van die sondaar versoening en hoop bring en die vrag van ons sondes van ons skouers afhaal.

Belydenis is 'n saak tussen God en mens. Barth beklemtoon dat God in Jesus Christus mens geword het en nie 'n instituut nie: Nachdem Gott selbst Mensch geworden ist, ist der Mensch das Masz aller Dinge ... (sodat die mens in alle handelinge) sich ... in erster Linie des Menschen und nicht irgend einer Sache annehmen wird (Barth 1946:25). Die feit dat die kerk later organisatories instituut geword het, was die gevolg van die noodsaak aan orde. Al kan die kerk vandag nie anders bestaan as om in 
'n geordende instituut te funksioneer nie, moet die kerk in die persoonlik-eksistensiële moment van die belydenisgebeure telkens iets beleef van die varsheid, eenvoud en $\mathrm{krag}$ wat in die vroeë kerk geleef het toe gelowiges met die belydenis dat Jesus die Here is, geleef en getuig het in die wêreld. Barth (1947:22) stel hierdie persoonlik-eksistensiële verhouding tussen God in Jesus Christus, en mens as verlore sondaar, duidelik wanneer hy oor die genade van God handel:

Es geschah, daß Gott Mensch wurde, Mensch war und ist. Und es geschah, daß Gott als dieser Mensch...leiden mußte und starb .... Und es geschah, daß dieser Mensch, der Gott war, von den Toten auferstanden ist .... Das ist die Geschichte zwischen Gott und dem Menschen, die Geschichte von Jesus Christus ... diese Geschichte ist es, die nach Fortsetzung ruft im Handeln des Menschen. Diese Geschichte geht ja den Menchen an, und zwar den in der Tat lebenden Menschen. Diese Geschichte ist das Wort, welches nach des Menschen Antwort ruft, die er mit seiner Tat zu geben hat. Jesus Christus ruft nach Nachfolge, d.h. nach einem menschlichen Leben auf dem von ihm eröffneten Wege ...

Die handeling van geloof, soos betuig in die belydenis, is dus 'n saak wat die totale mens raak wat bely - dit is 'n saak van hart, verstand en hand - dit groei uit die direkte ontmoeting en verhouding met God en die persoon van Jesus Christus en nie die dog-mas oor God en Jesus nie. Dit is waarskynlik waar die probleem in meeste gevalle lê, naamlik dat kerke en gelowiges wat die gees van die modernisme adem, eerder hulle heil soek in koue harde en onpersoonlike formules. Indien die kerk van die een-entwintigste eeu kerk van Jesus die lewende Heer wil bly en die proses van sekularisasie wil keer sal daar by hierdie punt begin moet word. Die krag en vitaliteit van persoonlike geloof loop dus voortdurend die gevaar om deur die dwangbuis van 'n ondeurleefde instemming met tradiosionele formules of dogmas verswelg te word. Die beslissende element van belydenis lê egter daarin dat persoonlik-eksistensiële geloofsbelydenis in die eerste plek ' $n$ persoonlike handeling van totale oorgawe aan die persoon van Jesus beteken. Bonhoeffer (1972:382) stel die vraag na die betekenis van die persoonlike belydenis in krisis bo alle twyfel waar hy in die dodesel die volgende daaroor sê:

What do we really believe? I mean, believe in such a way that we stake our lives on it? The problem of the Apostles' Creed? 'What must we believe?' is the wrong question; antiquated controversies, especially 
those between the different sects; the Lutherans versus the Reformed, and to some extend the Roman Catholic versus Protestant, are now unreal .... The faith of the Bible and Christianity does not stand or fall by issues. Karl Barth and the Confessing Church have encouraged us to entrench ourselves persistently behind the 'faith of the church', and evade the honest question as to what we ourselves really believe. That is why the air is not quite fresh, even in the Confessing Church .... We cannot, like the Roman Catholics, simply identify ourselves with the church.

Mens raak egter tog benoud wanneer 'n massiewe kerklikheid dreig om die getuigende handeling van persoonlike geloofsbelydenis te versmoor. So 'n massiewe kerklikheid loop altyd die gevaar om in sogenaamde ou sekerhede, stellings en vastighede heil en sekuriteit te gaan soek. Aan die ander kant lei eensydige en ongeordende getuienis weer maklik tot willekeur en selfs dwaalleer. Binne en saam met die geloofsgemeenskap en saam met die kerk van alle tye word die eenheid en waarheid van die belydenis bewaar en gekoester.

\subsection{Die vraag na 'n nuwe belydenis}

Dit is ' $n$ merkwaardige feit dat die belydenis van die kerk die bewoë stryd en gepaardgaande krisis van die geskiedenis en teologie weerspiël waaruit die belydenisse gegroei het (Van Wyk 1985:16). Die groei en ontwikkeling van die kerk se belydenis asook die ingrypende beslissings wat die kerk telkens moes neem, spreek van intense stryd ter wille van die waarheid, van ' $n$ intense begeerte na 'n ontmoeting met die persoon van Jesus die Here. Hierdie stryd het die kerk en die gelowiges diep geraak. So is Athanasius vyf keer verban, Guy de Bres het na die opstel van die Nederlandse Geloofsbelydenis ses veelbewoe jare ervaar voordat hy op 31 Mei 1567 tereggestel is. Die veelbewoë stryd van die Reformasie het die uitbreiding van die belydenis van die kerk meegebring, 'n uitbreiding wat nooit bedoel was om die antieke belydenisse te vervang of te verdring nie - trouens dit het die ou belydenisse eerder sterker in die hart van die kerklike verkondiging laat wortel skiet. Al dra die belydenisse van Nicea en Konstantinopel die stempel van 'n Grieks-Romeinse konteks en dié van die Reformasie spore van die denkstrominge van die tyd waarin dit ontstaan het, ontmoet die kerk in hierdie belydenisse Jesus die Here op 'n uniek-persoonlike wyse.

Die vraag wat dringende aandag van die kerk vandag vra, is of die krisis wat die modernisme en gepaardgaande sekularisasie gebring het 'n eietydse belydenis nodig maak, wat in hierdie gesekulariseerde wêreld die eksistensiële verhouding met die 
lewende Here opnuut kan verwoord. Die energie van die huidige debat oor die belydenis in die Hervormde Kerk behoort positief gestuur te word in die rigting van 'n nederige, biddende, belydende getuienis dat Jesus die Here leef, dat Hy in ons sondige bestaan verlossend en versoenend ingaan en dat ons hoopvol op sy toekoms kan wag wat die gelowige belyer eksistensieel in elke nuwe moment van ons sondige bestaan tegemoet kom. Dit is duidelik dat geen nuwe of eietydse belydenisse sonder ingrypende krisis ontstaan nie. Dit is egter ook duidelik dat die einde van die modernisme en die verskuiwings wat die postmodernisme in wêreldbeeld en lewensbeskouing besig is om te bring, ' $n$ ernstige besinning oor die belydenis en die funksionering daarvan in die kerk en veral in die liturgie vereis (Kelly 1982:32-37).

Die afgelope dertig jaar het, waarskynlik om genoemde redes, meer pogings tot eietydse belydenisformulerings opgelewer as enige tydperk in die geskiedenis van die kerk. 'n Hele aantal van dié belydenisse is persoonlik van aard en bedoel om die Christelike geloof toeganklik te maak vir die postmoderne mens. Karl Rahner (1978) se drie kort samevattings van die geloof, die twee belydenisse van Walter Kasper (1971) en die belydenis van Hans Küng (1976) is enkele van die bekende eietydse belydenisse wat gepoog het om die krisis van ons tyd aan te spreek. Hiermee saam het quasi-offisiële belydenisuitsprake wat formeel deur betrokke kerke aanvaar, is verskyn soos die Statement of Faith van die United Church of Christ (USA) in 1966, die nuwe belydenis van die United Church of Canada in 1968 en die Confession of the United Presbyterian Church of the USA in 1967 en die Confession of Faith van die Presbyterian-Reformed Church in Kuba wat in 1977 gepubliseer is. Daar is ook die voorbeeld van groepering van kerke soos die ses protestantse kerke in Skotland wat 'n gemeenskaplike belydenis The Faith of the Church in 1978 aanvaar het (Rodd 1987:125-138).

\section{EKSISTENSIëLE GEBEURE EN OBJEKTIEWE WAARHEID IN DIE BELYDENIS}

Alle kerke of geloofsgemeenskappe kies vir 'n formulering of formulerings van die geloof wat hulle bely wat tegelyk as afgrensing teen die tradisies van ander geloofsgemeenskappe en omlyning van die eie geloofstradisie dien. Die gewig en plek wat aan die bepaalde belydenisdokumente toegeken word, verskil van kerk tot kerk. Volgens Pannenberg (1987:141-143, 146) het die vroeë kerk se belydenisdokumente primêr as uitdrukking van die geloof en veral ook die lewe van gelowiges gefunksioneer. Die vroeë kerk het die belydenis langs en saam met ander wyses van geloofsverwoording gebruik, soos die liturgie en die struktuur wat die kerk binne die gegewe konteks aangeneem het. Kerke wat later in die geskiedenis van die kerk 'n eie onafhanklike ontstaan gehad het, was meer geneig om aan die belydenisdokumente 'n basiese grondlig- 
gende belangrikheid toe te ken, naamlik as dokumente wat getuienis lewer van die kerke se universele beroep op die egte Christelike waarheid wat dan terselfdertyd dien as legitimering van hulle afsonderlike bestaan of totstandkoming. Dit is veral die kerke van die Reformasie wat hoë waarde aan die belydenisskrife toeken, aangesien die identiteit van die kerk veral duidelik deur die dokumente uitgedruk en omlyn word; die identiteit wat die kerk deur die aangesproke Woord in ontmoeting met die Heer van die kerk telkens opnuut bevestig en betuig.

Die Apostoliese belydenis wat uit die dooponderrig van die vroeë kerk ontstaan het, het in die opsig gefunksioneer as bondige samevatting van die geloof van die geloofsgemeenskap en het as sodanig eksistensieel uitdrukking gegee aan die viering van die geloofservaring in die liturgie van die belydende gelowiges. Die Apostoliese en Niceense belydenisse beklee steeds 'n prominente plek in die liturgie van die meeste Reformatoriese kerke soos die Hervormde kerk. Dit is egter 'n ongemaklike vraag of dié belydenisse telkens opnuut in die liturgie die funksie vervul van eksistensiële uitdrukking van die ontmoeting met die lewende Heer van die kerk. Die vraag kan ook verder gevoer word en betrek word op die aflegging van die belydenis van geloof. Verteenwoordig die belydenis werklik 'n ontmoeting met die Heer of is dit dalk in die in die meeste gevalle slegs 'n herhaling van woorde wat niks anders as vormgodsdiens verteenwoordig en daarom leeg en betekenisloos vir die gemeente en die jong belydende gelowige is nie? Die belydenis moet daarom dalk meer gebid, gesing en gepreek word - dit kan daartoe bydra dat die belydenis meer 'n saak van die hart, van eksistensiële betrokkenheid van die hele mens word.

Die begrip 'belydenis' het nie vir alle teoloë dieselfde betekenis nie. Sommige sien dit as die lewende getuienis van die kèrk in die tyd-ruimtelike situasie waarin die kerk optree en getuig. Ander weer verstaan onder 'belydenis' die gefikseerde leer van die kerk wat óf mondeling of skriftelik bely word. 'n Derde moontlikheid sluit beide moontlikhede in. Die belydenis kan positief of as uitdrukking van die geloof van die kerk of negatief as verstarde leer van die kerk funksioneer. Die vraag is of die belydenis eers bely is, sodat die belydenis van die kerk op grond van hierdie getuienisdaad tot stand gekom het, of was die belydenis as gegewe, as geopenbaarde saak, reeds daar wat net bely moes word. In laasgenoemde geval beteken dit gewoon die nasê van dit wat eens en vir altyd volkome, afgeslote en volmaak gesê is. Dit sou verder beteken dat die belydenis as saak, dit is die gefikseerde belydenis, onveranderlik is - 'n ewig, onaantasbare saak. Aan die ander kant, as die daad van belydenis die klem ontvang waar die gefikseerde belydenis inderdaad uitdrukking word van die lewende belydenis van die kerk as geloofsgemeenskap op 'n bepaalde plek en binne die konteks van 'n spesifieke tyd, word die belydenis as saak prinsipieel oop en veranderlik verstaan. 
Die waarheid van die belydenis kan nie ontmoet word as 'n ewig abstrakte idee of konstruk, soos die godsbegrip voorgestel word in die skemas van baie filosowe nie. Die kerk as geloofsgemeenskap ontmoet die waarheid van die belydenis altyd as 'n Persoon. In die mens Jesus van Nasaret het God die Vader sy gesig aan ons gewys. Wanneer die kerk in hierdie lewende ontmoetingsgebeure beleef hoe Jesus Christus werklik vir gelowiges is en word, wat Hy doen en sê, wéét gelowiges - só is God! Hierdie wete veronderstel ' $n$ breër rasionaliteit as slegs rasionele oortuiging, gebaseer op wat deur die kenvermoëns van die menslike denke bepaal word. Wie hierdie man sien, wie Hom ontmoet, sien en bely God die Vader wat Hom gestuur het. Hierdie ontmoeting tussen gelowiges en Jesus die Here, roep om ' $n$ beslissing - op ' $n$ antwoord op die vraag: 'Wie sê die mense is Ek?' Die antwoord op hierdie vraag is 'n geloofsantwoord waarin gelowiges in hulle totale eksistensie geroer en aangegryp word - dit is ' $n$ saak van hart, verstand en hand. Belydenis word so 'n antwoord wat telkens gewaag word vanuit hierdie Godsontmoeting waar die 'Gans Andere' die gelowige in sy of haar sondige wêreld ontmoet. Dit kan nooit 'n volledige greep of verstaan van die 'Gans Andere' wees nie, gewoon omdat die mens wat ontmoet word, tog nie die God, die 'Gans Andere' kan besit en omvat nie. Omdat die mens voor die 'Gans Andere' te staan kom, bring die ontmoeting telkens die verwondering in die hart van die gelowige en die gemeente wat bely. Die ongemaklike vraag wat so deursny na die hart en wese van die belydende kerk, is of dié verwondering by hierdie mense voor God steeds daar is.

Die belydenis as saak is daarom net moontlik omdat en waar gelowiges deur God se Woord en Gees in ontmoeting begelei is tot voor God. Die Waarheid is tog 'n Waarheid wat my die belyer in 'n lemand, in Jesus die Here se teenwoordigheid bring. Daarom kan geen gelowige as toeskouer van die Waarheid praat nie, maar alleen as gelowige wat deur die Waarheid eksistensieel aangegryp is (Koekemoer 1995:596-599).

Die belydenis as daad, word dan asof vanselfsprekend die belydenis as gefikseerde saak. Dit konstrueer nie soseer die Waarheid nie, dit getuig van die Waarheid. Dit kan daarom nooit die volheid van die Waarheid ontmoet en gryp nie, want dit sou beteken dat mense God in formules kan ingiet, in formules en konsepte kan laat verstar. Dan sou dit moontlik wees dat die kerk en mense oor God self kan beskik wat tog ondenkbaar is. Dit is egter wat filosowe deur die eeue telkens gepoog het om te doen. In 'n sekere sin is dit ook wat by die Rooms-Katolieke Kerk gebeur waar belydenis en kerklike dogmas as geopenbaarde waarhede in die onfeilbare leergesag van die kerk besit word. By die Rooms-Katolieke kerk staan die Bybel nie meer vry in outoriteit teenoor die kerk nie, die kerk het in dié geval die Bybel gevange geneem waar die belydenis en dogma as onfeilbare en volmaakte openbaringswaarheid geld. In so 'n geval sou die kerk inderdaad kon verklaar dat hulle die waarheid het. In die Protestantse denke gaan dit nie om wat die kerk by wyse van geopenbaarde waarheid het nie, maar om wat die kerk glo. 
Mens sou dus slegs van die 'objektiewe' van die belydenis kon praat in die sin van Wie ons glo. God is altyd groter as wat ons kan dink en sê. Hy is die 'Gans Andere'. Sy werklikheid betree in die ontmoetingsgebeure die werklikheid van die mens, maar dit word nooit die besit van mense nie. Hy is elke keer wanneer die belyer of belydende kerk Hom in die belydenis ontmoet vir die belyer 'n verassing en vervul die belyer met verwondering. Daarom kan ons nooit sê dat die belydenis as daad of selfs as saak die volmaakte en afdoende draer van die Waarheid is in die sin van 'n objektiewe waarheid wat objektief deur 'n kennende subjek geken kan word soos dit inderdaad die opvatting in die paradigma van die modernisme was nie. Newbigin (1991:2930) waarsku juis teen so 'n opvatting:

From Descartes onwards it has been held by the relentless exercise of the critical method .... What is left, as Nietzsche saw, is the will to power .... Any claim to know the truth is, therefore, simply a concealed assertion of power .... Reason, even the most acutely critical reason, cannot establish truth. And it naturally follows, as a further development of the Nietzschean scenario, that words are treated as nonreferential .... Any claim to know the truth is a claim -- well- or ill-disguised - to exercise power.

Die kennis van God word telkens deel van die hele lewe van die gelowige subjek wat deur die Subjek, God in Jesus Christus, ontmoet word. Newbigin (1991:33) wys daarop dat die 'kennis' van die waarheid wat in 'n eksistensiële ontmoetingsgebeure in 'n subjek-Subjek verhouding openbaar word 'envolves struggle, feeling one's way'. Die riskantheid van hierdie eksistensiële worsteling om te 'weet' in terme van die Goddelike werklikheid en waarheid, kan nooit 'n volledige en afgeslote kennis van God wees nie.

All our knowing is a personal commitment in which we have no external guarentee that we cannot be mistaken. But we only grow in knowing as we take risks and accept responsibility. Descartes's program of indubitable knowledge is a fatal blind alley. All knowing is the knowing of a fallible human subject who may be wrong but who can only know more by personally committing himself to what he already knows. All knowing is a personal commitment. Does that mean, then, that knowing is purely subjective? No! It is a matter of personal commitment, but 
commitment to the understanding of a reality which is not in my mind but 'out there'... The alternative to subjectivity is not an illusory claim to objectivity, but the willingness to publish and to test. And this has obvious relevance to the Christian claim that Jesus is the true and living way, the master clue by following whom we shall be led into the truth.

(Newbigin 1991:33)

Die belydenis kan om dieselfde rede nooit op 'n gegewe punt in die geskiedenis geld as volmaakte en klaar geformuleerde uitdrukking van die Waarheid nie. Die implikasie van die afleiding is dat die belydenis nooit ' $n$ doel in sigself kan en mag word nie. Die belydenis is nie soseer woord nie, maar eerder antwoord (Velthuysen 1982:54).

Die belydenis as antwoord op die ontmoeting met die Heer van die kerk se oorsprong is geleë in die Woord en Gees van God. Hierdie geloofsantwoord van die geloofsgemeenskap word telkens geartikuleer in taal met gebruikmaking van begrippe en woorde wat in ' $n$ bepaalde situasie gewortel is, binne die grense van ruimte en tyd. Dit impliseer intellektuele, sistematiserende dinkwerk met gebruikmaking van bepaalde denkkategorieë en is gevolglik menslike werk - maar dan menslike antwoord wat wakker geroep is deur die ontmoeting met die lewende God. Daarom hoor mens in die belydenis meer as net intellektueel-rasionele menseskepping - jy hoor die geloof van die kerk wat aan die woord kom as verwonderde antwoord van die gelowige belyer.

Hierdie belydenis is antwoord, aanvaarding en proklamasie van die geloof in Jesus Christus; wie $\mathrm{Hy}$ is en wat $\mathrm{Hy}$ vir die gelowige beteken. In die sin het of besit die gemeente of kerk natuurlik nie 'n belydenis nie, maar word die gelowige of kerk in die belydenis wat die gemeente of kerk in Jesus die Here reeds is (Pont 1985:524). Daarom stel Artikel 27 van die Nederlandse Geloofsbelydenis dan ook dat die kerk 'n heilige vergadering van ware Christengelowiges is wat nie anders kan as om te bely dat Jesus Christus die Here is nie. Belydenis in die mond en hart van die gelowige en die kerk moet 'n lewenswyse word wat sigbaar moet word in die ruimte van die gemeenskap van gelowiges onderling en hulle uittree na die wêreld van ongeloof.

The Church lives by the faith that (to put it in a very truncated form) Jesus is Lord. That means that He is Lord not only of the Church but of the world, not only in the religious life but in all life, not merely over some peoples but over all peoples .... We have no way in which we can demonstrate the truth of that claim by reference to some supposedly 
more ultimate realities .... We do not have all truth, but we know the way along wich truth is to be sought and found .... That is the only way we affirm that the gospel is not just 'true for us' but true for all.

(Newbigin 1991:34)

Só gesien is die kerk belydende kerk wat die roeping aanvaar om die belydenis van die kerk te bely. Die belydenis kan dus nooit net 'n objektiewe teenoor die belyer wees nie, maar moet telkens die eie antwoord van die belyer word. In 'n sekere sin kan die uitdrukking die belydenis problematies word, inderdaad 'n contradictio in terminis, want die belydenis is nie 'n objektiewe gegewene in die sin van die modemistiese betekenis van die woord nie.

\section{SAMEVATTING}

\subsection{Die gelowige se identiteit blyk uit die wyse waarop bely word}

Die belydenis of ' $n$ belydenis soos Pont (1982:519-546) verkies om daarvan te praat, is net soos die kanon, 'n maatstaf wat vra om 'n persoonlike beslissing. Dit vra na die self van die belyer, hoe hierdie belyer voor God in Jesus die Here is en word. Oberholzer het in 'n ongepubliseerde voordrag voor 'n predikante ringsraad van Krugersdorp die volgende stelling oor die Bybel en belydenis gemaak wat die identiteit van die gelowige aanraak:

Die Bybel is ' $\mathrm{n}$ boek, ' $\mathrm{n}$ versameling van boeke in twee dele, bedoel om gelees en verstaan te word;

Die Kanon is 'n maatstaf wat vra om 'n persoonlike beslissing: Wie is ek en wat moet ek doen? Wat kategories gesaghebbend is, is nie die Bybel of gedeeltes van die Bybel nie, maar wel woorde in verhouding tot ander woorde in verhouding tot tyd en situasie ...;

Die Ou Testament vertel en vertoon 'n geskiedenis tussen God en mens ... en vertoon ' $n$ bepaalde gerigtheid op ' $n$ toekoms binne die tyd en by die grense van tyd verby ...;

Die Nuwe Testament vertel en vertoon 'n geskiedenis tussen God en mens ...; en

Die belydenis van die kerk maak van die boeke van die Bybel 'n eenheid en stel die eis van prediking uit die geheel.

(Oberholzer 1996) 
Belydenis en prediking word net 'n probleem, 'n verleentheid, wanneer vergeet word (hetsy bewustelik of onbewustelik) van die geskiedenis tussen God en mens - 'n geskiedenis wat vir die gelowige 'n lewende ontmoeting word met die Persoon van Jesus die Here. 'n Teks het 'n plek en 'n tyd binne die geskiedenis en word net reg gelees, eksistensieel begryp, in 'n verhouding tot die geheel van die geskiedenis. Daarom sê Oberhozer (1996) dat Christus 'nie in die Ou Testament (is) nie maar in die geskiedenis waaroor die Ou Testament handel.' Hy sê verder dat 'die kanon homself opdring as 'n geskiedenis tussen God en mens (wat God gedoen en gesê het teenoor mense en wat mense gedoen en gesê het in antwoord daarop oor 'n bepaalde tydperk).'

As gelowige vind ek my identiteit in die manier waarop ek met die Bybel omgaan. Saam met die mense in die Bybel vind ek my identiteit as gelowige saam met hulle voor God. Daar kan nooit ontken word dat die mens ook binne 'n geloofstradisie leef waarin telkens wéér oor God gepraat is en wéér gepraat sal moet word nie. Belangrik is dat hierdie gesprek nooit op so 'n wyse mag verstar dat dit inderdaad in God self verander nie. Natuurlik is teologie geen esoteriese bedryf nie. Dit is denkaktiwiteit ten dienste van die kerk. Daarom behoort belydenisformules nie verstar nie, maar behoort dit eksistensieel 'n ontmoeting bewerkstellig (Koekemoer 1995:598-599). Waar belydenis in formules verstar, bring dit die dood in die gemeenskap van gelowiges. Dan is geloof nie meer ' $n$ lewe coram Deo nie, maar slegs die intellektuele aanvaarding van verstarde dogmas wat die kerk in die loop van eeue vasgestel het. Dan kan mens verstaan dat sommige lidmate belydenisskrifte ervaar as museums vol interresante oudhede. Saam met die mense van die ou credo's van die vroeë kerk, vind die gemeenskap van gelowiges hulle identiteit as mense, as verloste sondaars sáám voor God. So word die eenheid van gelowiges wat die persoon van Jesus eksistensieel bely, nie in objektiewe formules gegrond nie, maar in ontmoeting met die Persoon, Jesus die Here. Alhoewel ons dink en selfs praat in en met behulp van leerstukke, dogmas en sisteme word dit juis uit hierdie ontmoeting duidelik dat geen leerstuk, dogma of sisteem die volle waarheid van God kan omvat nie. Dié besef is inderdaad vir die gelowige en die kerk ' $n$ bevryding. Die belangrikheid van die kerklike belydenisformules en leer lê dan daarin dat dit as kerklike verwoording van die ontmoeting met God tot 'n nuwe ontmoeting met God lei (Berkhof 1973:32).

Geloof word in lied en gebed die helderste gehoor en beleef. Prediking, lied en gebed as eksistensiële woord-antwoord gebeure, word inderdaad in elke tyd en situasie uitdrukking van hierdie kosbare ontmoetingsgebeure van gelowiges met God. Waarheid as ontmoeting, in Brunner se woorde, as ontmoeting met die Persoon van Jesus die Here sou, as dit nuut ges $\mathbf{e}$ word midde in die krisis wat die post-Kopernikaanse tyd waar God verdof is deur idees oor Hom, die verwondering voor die lewende God terugbring in die harte van die mens van die een-en-twintigste eeu. 


\subsection{Belydenis en eskatologiese verwagting}

Bybelse eskatologie relativeer in 'n sekere sin alle vorme. Soos die opstanding van Christus lig werp op die lewe van Jesus in sy vernedering, so werp die toekoms met die Heer reeds strale van hoop op die geskiedenis van hierdie wêreld van die dood. Die kerk hanteer die eskatologie soms bloot as slothoofstuk van die heilige huisies en vaste vorme waarin ons meen om sekuriteite te vind. Ons verwagting van die komende ryk van God waar elke nuwe moment in die hede ons met die toekoms konfronteer, maak die gelowige onrustig in hierdie wêreld. Terugkyk bedoelende na bepaalde vorme, moet die kerk onthou, kan ook 'n vorm van ongeloof wees omdat gelowiges Jesus die Here tegemoet gaan (Barth 1947:22). Dit gaan hier nie om 'n toekomsideaal nie, maar om die verwagting van die volle openbaring van die Heiland van die wêreld, Jesus die Here. Stellig dreig hier aktivisme en werkheiligheid - maar as dit nie gebeur nie, kan die kerk net so skuldig staan voor die gevaar van kwiëtisme! 'n Kerk wat eskatologies bely sal in die prediking en teologie eenmaal moet waag om op die smal lysie te beweeg, wetende dat aan albei kante van die lysie afgrond is. Hoeseer dit ook al waar is dat alle verwagtinge van die ryk van God steun op die sekerheid dat alles reeds volbring is, dat die toekoms nou reeds is, is dit eweseer waar dat die aanvaarde belydenis en die hoop wat gelowiges op die Heer laat wag, geleef moet word deur belydende en hopende Christene. Lewe is ook handeling. Weereens kan dit gevaarlik word as alles in die etiek sou opgaan. Tog is dit so dat die erns van die eskatologie blyk in die etiek. Inderdaad blyk die relevansie van belydenisuitsprake uit die lewe van die gelowiges.

\subsection{Eietydse belydenis en die krisis van die post-Kopernikaanse tyd}

Die kerk sal moet oordeel of die krisis van die tyd 'n eietydse belydenis vra. As ons in aanmerking neem dat belydenisse altyd in tye van groot krisisse ontstaan het, sal die kerk in die tyd van massiewe ontkerkliking moet oordeel waar die wortel van die ontsporing lê. Van Zyl (1994:5) maak die opmerking in 'n artikel in Die Hervormer dat die teologie in hierdie gesekulariseerde en postmoderne tyd die klem sterker op die doen en minder op die sê van die kerk moet laat val. Dit behoort baie meer gesteld te wees op die hande, die voete en op die mond van die geloof en die belyer. As dit waar is dat die kerk en teologie eietydse taal, begrippe en voorstellings nodig het om verstaanbaar en eksistensieel te kommunikeer, beteken dit inderdaad dat wat hulle wil sê, onverstaanbaar en selfs waardeloos kan wees as dit nie in elke nuwe situasie anders gesê word nie. Sodra mense begin om te ervaar dat nie hulle verhouding met God nie, maar hulle verhouding met die kerk en die gesag van vergaderings voorop staan, verstar die lewe van die gemeente. Die tendens word sterker waar ouer mense al meer 
krities na die kerkwees van die kerk kyk, terwyl jongmense nie dieselfde liefde vir die kerk toon as vroeër nie en na innerlike godsdienssekerheid oral op die 'markplein' rond soek. Die vraag is of die jongmense (en ouermense) nie dalk weggeskok word deur die koue, afsydige en formele leefwyse wat so dikwels in gemeentes aangetref word nie. Wat natuurlik net nie meer opgaan in die postmoderne tyd waarin die kerk vandag leef nie, is dat magsgeoriënteerheid die eksistensiële ontmoetingsgebeure waarvan die belydenis verwonderd getuig, oorwoeker. Hierdie koue formele onpersoonlike leefwyse stoot ook deur na die ouerhuis, skool en gemeenskap. Indien ouers, predikante, kerkraadslede en gemeentes nie met innerlike toewyding, omgee en opregtheid vanuit die eksistensiële ontmoeting met die Heer van die kerk léf nie, gaan sekularisasie die dood bring van ' $n$ god wat as blote idee of projeksie in mense se verstand funksioneer. Dit is juis waarvan Nietzsche gepraat het. Feit is dat belydenis, die aktiewe persoonlike belydenis wat uit die hart geruk is, die gelowige so moet aangryp dat dit spontaan invloei in lied, die gebed en in die lewe van gelowige en gemeente. 'n Eietydse belydenis sal egter nooit die ou credo's kan vervang nie. Dit sou die Waarheid, die Persoon Jesus Christus, te midde van die krisis van die tyd waar koue rasionaliteit, onpersoonlikheid bestaan en ongeloof vervreemding van die self en van God gebring het, helder, suiwer opreg en eksistensieel moet oorsê in die konteks van die dag. Voordat dit egter oorweeg word sal die kerk dit moet uitmaak of die krisis van sekularisasie en van die modernisme dit nodig maak.

Dit is natuurlik waar dat ' $n$ belydenis nie sommer gemaak word nie. Dit tree daar na vore waar die kerk in die konkrete nood van die dag niks anders kan doen, niks anders het om aan te bied as net om te bely nie. Juis in die situasie van konkrete en eksistensiële krisis kom die kerk tot belydenis. Terselfdertyd sal daar gewaak moet word teen situasieteologie en teen verdeling. Daarby sal ook in gedagte gehou moet word dat belydenis die band van eenheid tussen geloofsgenote versterk (Breytenbach 1982:50).

Ook Van Aarde (1985:572) sê dat die klassieke dogmas telkens nuut gesê moet word. Herinterpretasie vereis volgens hom nie in beginsel nuwe belydenisskrifte nie. Die eventuele ontstaan van nuwe belydenisskrifte kan die gevaar inhou dat die kontinuïteit met die bakermat van die Reformatoriese tradisie mettertyd prysgegee kan word. Aan die ander kant moet die waarskuwing ook gehoor word dat blote herhaling sonder herinterpretasie die kenmerk van die ortodokse is. Herinterpretasie veronderstel volgens Van Aarde kontinü̈teit, nieteenstaande die feit dat dit 'n korrektief kan insluit. 
'n Eietydse belydenis kan natuurlik verstarring wat altyd in die sirkel tussen die pole van Woord en belydenis latent is, deurbreek. Dit is iets wat inderdaad met die vroeë credo's en gedurende die Reformasie gebeur het. Die situasie, die nood in die situasie, deurbreek die sirkel deur eie en nuwe antwoorde van die geloof te vra. Van Zyl wys tereg daarop dat die postmoderne tyd die klem sterk op die doen van die kerk laat. Hierdie verskuiwing het natuurlik teen 'n bepaalde agtergrond ontstaan waar die kerk juis getoets word aan die realisering van wat gepreek word. Dit gaan hier om die eksistensiële leef van die geloof wat bely word. Hy maan dat die kerk die waarheid van die Skrif wat ons in ' $n$ bepaalde woordvorm het en wat die kerk in ' $n$ bepaalde formulering as sy geloof bely, krities moet herinterpreteer vir sy eie tyd (Van Zyl 1994: 4). Hy gaan voort deur die volgende opmerking te maak:

As dit waar is dat die Kerk en teologie eietydse taal, begripvoorstellings nodig het om verstaanbaar te praat, beteken dit inderdaad dat wat hulle wil sê, onverstaanbaar en dalk waardeloos sal wees as dit nie in elke nuwe era anders gesê word nie. Die eras volg mekaar een na die ander op in die wêreld, hulle verander, maar daar is net een ewige, onveranderlike evangelie. Hierdie evangelie moet egter in die wisselende geestesgesteldheid van die wêreld anders gesê word.

(Van Zyl 1994:5)

Die kerk se teologie en die belydenis kan nie bekostig om in tydlose en verhewe vlugte bokant die situasie te bly sweef nie. Die kerk moet eenvoudig met die belydenis dat Jesus die Here is in die lewenswerklikheid van die dag ingaan. Belydenisse moet egter steeds gelees word teen die agtergrond van 'n bepaalde geloofstradisie wat die ontstaan daarvan beïnvloed het. 'n Geloofsgemeenskap doen dit egter nie in isolasie nie. Die vadere, wat saam met ons die een heilige algemene kerk is, het ook inspraak. Hulle inspraak tree in ons belydenistradisie na vore. Ons moet dit uiteraard ernstig neem. Maar dit is nie goed genoeg om net te herhaal wat hulle inspraak na vore roep nie. Wie dit doen, het nog nie self tot 'n eksistensiële belydenisontmoeting gekom nie. Dan is daar ook nog nie werklik erns gemaak om na die stemme uit die verlede te luister nie. Belydenis is 'n eksistensiële saak coram Deo (vgl Koekemoer 1995). Goddefroy (1889:11) oordeel dus reg as hy sê dat die suiwere leer by Hervormers nooit of te nimmer die leer van die vadere, of die konsilies is nie, maar altyd en alleen wat die Heilige Skrif ons leer. Dit is die saak waarom belydenis draai en hierin het beide ons en die vadere die een gemeenskaplike bron in die Persoon voor wie ons te staan kom, Jesus 
die lewende Here. Die Persoon wat die belydende kerk ontmoet, of dit is soos in die konteks van die vadere, of in die konteks van die mens vandag in gesekulariseerde en postmoderne idioom, bly dieselfde. Hy bly dieselfde nie in die sin van ' $n$ afgeleide rasionele idee of begrip nie, maar soos ons Hom telkens ontmoet in die Woord en deur die belydenisse van die vadere.

Die mens in omtmoeting verander egter en die wêreldbeskouing en -beeld van die postmoderne, gesekulariseerde mens skep eenvoudig 'n ander konteks. Hierdie konteks moet beide in positiewe en negatiewe sin beoordeel word. Feite soos die beskouing oor die pluraliteit van waarheid (meerkantigheid), funksionele denke, groter klem op die doen as op die sê, en veral die behoefte aan ontmoeting en verhouding, het implikasies vir die bestaanswyse van die kerk in hierdie gesekulariseerde wêreld en die verstaan en belewing van God soos gelowiges Hom ontmoet in en deur die Woord. Die mens van die postmoderne tyd ken net die voorhande wêreld - daar is egter 'n diepe begeerte merkbaar in die soeke na 'n meerdimensionele werklikheid. Die kerk sal oor die saak ernstig moet besin - is die krisis van die gesekulariseerde, postmoderne mens so groot dat dit vra om 'n eietydse belydenis. Indien die kerk so sou oordeel sou dit as eietydse belydenis die saak van die anieke belydenisse saam met dié belydenisse moet nasê. Soos die vroeë kerk se belydenis moet dit ons vandag ook eksistensieel vasgryp, sodat ons dit móét sê, en só sê dat die negering van die halwe waarheid en die leuen daarin ingesluit word.

\subsection{Wil die kerk nog in hierdie tyd Jesus as Heer van die kerk bely?}

Belydenis van die kerk of van 'n gelowige is nie blote instemming met 'n geskrif nie. God is eenvoudig groter en meer as wat in 'n geskrif onder woorde gebring kan word. Wat in 'n belydenisskrif vasgelê word, is belangrik omdat die gelowige deur baie oë en met baie ore en monde die verwondering van die ontmoetingsgebeure met die Heer van die kerk kan stamel. Ons wat vandag oor hierdie allesomsluitende wonder stamel, besef dat dit slegs maar pogings is van mense wat deur hierdie ontmoeting beweeg en ontroer word. Inderdaad volg hierdie stameling op die besef van menslike geringheid aan die een kant en God se liefde vir die sondaar daar waar mense in opregte geloof voor die lewende God te staan kom. Daar word harte, hande en verstande beweeg op grond van die volle oortuiging en belydenis dat Jesus die Here is.

Die gevaar waarteen die kerk altyd moet waak, is dat belydenisskrifte nie daar is om as strategieë gebruik te word nie. Behalwe die onopregtheid wat uit so 'n misbruik blyk, verloor die belydenis dan die bedoeling en krag daarvan. Dan hou belydenis inderdaad op om belydenis te wees. Waar 'n kerk se struktuur en voorkoms in die wêreld bepaal word deur 'n belydenisdokument as objektiewe gegewene, hou daardie 
kerk op om belydende kerk te wees. Van so 'n kerk sou mens hoogstens kan praat as 'n belydeniskerk. Dit wil geensins beweer dat vir 'n belydende kerk die belydenisgeskrifte vervaag in onbelangrikheid nie, inteendeel waar opregte geloof in Christus geleef word, word die belydenisskrif en veral die saak wat dit verwoord, ook telkens weer ' $n$ geleentheid om eksistensieel in één geloof saam met die kerk van vroeër die wonder van die Godsontmoeting te stamel. Hier staan die geformuleerde geloof dan nie in die sentrum nie, maar die lewende geloof. Dit beteken natuurlik nie dat geformuleerde geloof teenoor lewende geloof hoef te staan nie. Die geloof van mense wat voor God leef, beteken inderdaad dat die geloof geleef moet word en dan so goed moontlik omskryf moet word. Die belydenis of belydenisskrif is ' $n$ ware en betroubare verwoording van die ontmoeting met God deur mense in bepaalde tye en omstandighede. Dit kan egter nooit 'n volkome weergawe wees van die God wat ons bely nie. Wanneer 'n belydenisskrif egter in die plek van God inskuif en voor ons te staan kom as dié waarheid het ons inderdaad te doen met abstrakte en finale waarhede wat tydloos bo en oor ons sweef, sonder om ons werklik te raak.

Die kritiese vraag wat ten slotte gevra moet word, is of kerk en lidmate nog lemand het om te bely. Dit kan alleen duidelik word uit die innerlike oortuiging van geloof en die die opregte lewe uit Christus. Dit is net moontlik waar die kerk en gelowiges voor God leef en bely.

\section{Literatuurverwysings}

Barth, K 1935. Das Evangelium in der Gegenwart. TEH 25, 3-20.

- 1946. Christengemeinde und Bürgergemeinde. TSH 20, 3-43.

— 1947. Die Botschaft von der freien Gnade Gottes. TSH 23, 2-28.

1953. Kirchliche Dogmatik, IV/1. Zürich: EVZ.

Berkhof, H 1973. Christelijke geloof. Nijkerk: Callenbach.

Bonhoeffer, D 1972a. Letters and papers from prison. London: SCM Press. 1972b. Het wezen van de kerk. Baarn: Ten Have.

Botha, S J 1982. Die belydenis in kerkregtelike verband in die Nederduitsch Hervormde Kerk van Afrika. HTS 38/2 \& 3, 30-44.

Breytenbach, A P B 1982. Die belydenis in hermeneutiese verband. HTS 38/2 \& 3, 45-51.

Cox, H 1984. Religion in the secular city: Toward a postmodern theology. New York: Simon and Schuster.

Deist F E 1994. Moet teologiese opleiding kerklik-konfessioneel wees? HTS 50/1 \& 2, 53-67. 
Gemser, B 1944-45. Die organiese eenheid van objektiewe Bybelondersoek. HTS 2, 49-65.

Goddefroy, M J 1889. Die kerkkwessie niet een leer - maar een lewenskwessie. Tweede druk. Den Haag: De Swart \& Zoon.

Kasper, W 1971. Kurzformel des Glaubens, in Roman Bleistein, vol 2. Würzburg Echter Verlag

Kelly, J N D 1982. Early Christian creeds. London: Longmans.

Koekemoer, J H 1995. Die etos van die Nederduitsch Hervormde Kerk. HTS 51/3, 876-880

Küng, H 1976. On being a Christian. London: Doubleday.

1991. Global responsibility: In seach of a new world ethic. New York: Crossroads.

Nederduitsch Hervormde Kerk van Afrik 1993. Diensboek. Pretoria: Gutenberg.

Newbigin, L 1991. Truth to tell. The gospel as public truth. Michigan: Eerdmans Publishing Company.

Oberholzer, J P 1996. Bybel en prediking. Ongepubliseerde voordrag gehou voor die Ringsraad vir predikante, Krugersdorp.

Ott, H 1981. Die Antwort des Glaubens. Berlin: Kreutz Verlag Stuttgart.

Pannenberg, W 1969. Theology and the kingdom of God. Philadelpia: Westminister.

-1987. The place of creeds in Christianity today, in Rodd, C (ed), Foundation documents of the faith. Edinburgh: T T Clark

Pont, A D 1982. Die belydenis in historiese verband. HTS 38/2 \& 3, 1-29.

1985. Die funksie van die belydenis en die dogma in die struktuur van die Nederduitsch Hervormde Kerk en die implikasies daarvan vir die predikant. HTS $41 / 4,519.546$.

Rahner, K 1978. Foundations of Christian faith. London: Darton, Longman \& Todd. Rodd, C S 1987. Foundation documents of the faith. Edinburgh: T T Clark.

Van Aarde, A G 1985. Skrifgebruik; Hermeneutiese riglyne. HTS 41/4, 547-578.

1993. Teologie vir die kerkvolk. Die Hervormer, 15 Augustus 1993.

- 1994. Teologie vir die derde millenium. Die Hervormer, 1 Februarie 1994.

Van Niftrik, G C 1961. Kleine Dogmatiek. Nijkerk: Callenbach.

Van Ruler, A A 1973. Hoe functioneert de belijdenis? Amsterdam: Visie en Vaart.

Van Wyk, D J C 1985. Wat is die kerk se belydenis? Die Hervormer, Mei 1985.

Van Wyk, I W C 1995. Die gemeenskap van die heiliges. HTS 51/3, 732-752

Van Zyl, F J 1994. Onveranderde evangelie moet telkens anders verkondig word. Die Hervormer, 15 Julie 1994. 
Velthuysen, G C 1982. Die belydenis in dogmatiese verband. HTS 38/2 \& 3, 52-61. 1985a. Die funksie van die belydenis in die struktuur van die kerk en die betekenis daarvan vir die predikant. HTS 41/3, 372-377.

1985b. Wat is Woord van God - Skrif, belydenis, prediking? HTS 41/3, 364-371. 